\title{
AN ANALYTIC NETWORK MODEL FOR SMART CITIES
}

\author{
Patrizia Lombardi \\ Politecnico di Torino \\ Department of Housing and Cities \\ Torino, ITALY \\ patrizia.lombardi@polito.it \\ Silvia Giordano* \\ SITI Innovation Research Centre of Politecnico di Torino \\ Torino, ITALY \\ silvia.giordano@polito.it \\ Hend Farouh \\ Housing \& Building National Research Center (HBRC) \\ Giza, EGYPT \\ hendfarouh@hotmail.com \\ Wael Yousef \\ Department of Urban Planning \\ Al-Azhar Univers ity \\ Cairo, EGYPT \\ dr_wael_yousef@yahoo.com
}

\begin{abstract}
This paper aims to offer a profound analysis of the interrelations between smart cities components connecting the cornerstones of the triple helix. The triple helix model has emerged as a reference framework for the analysis of knowledge-based innovation systems, and relates the multiple and reciprocal relationships between the three main agencies in the process of knowledge creation and capitalization: university, industry and government (Etzkowitz, 2008). This analysis of the triple helix will be augmented using the Analytic Network Process to model, cluster and begin measuring the performance of smart cities. The model obtained allows interactions and feedbacks within and between clusters, providing a process to derive ratio scales priorities from elements (Saaty, 2005). This offers a more truthful and realistic representation for supporting policy making. The application of this model is still to be developed but a full list of indicators, available at urban level, has been identified and selected from literature review.
\end{abstract}

Keywords: Analytic Network Process, Smart Cities components, Triple Helix Approach.

\section{Introduction}

Traditional neoclassical theories of urban and regional growth are often inadequate in analyzing the urban transformations of the 21 st century. Theories of regional competitiveness try to fill this gap by focusing not only on the city's endowment of hard infrastructures (physical capital), but also, and increasingly, on the availability and quality of knowledge communication, social and environmental infrastructure s (intellectual, social and environmental capital).

The application of information technology (ICT) in the context of future cities is often indicated by the notion of Smart City. This concept has been quite fashionable in the policy arena in recent years.

\footnotetext{
* Corresponding author
} 
Compared with the concept of digital city or intelligent city (Lombardi et al., 2009), the main focus is not limited to the role of ICT infrastructure but mainly on the role of human capita/education, social and relational capital and environmental issues. These are considered important drivers of urban growth.

In order to explore the concept of smart city, a revised triple helix model has been recently proposed by Lombardi et al. (2011) focusing on the production of knowledge by Universities and Government and the production of innovation which are patented by industry and university as an index of intellectual capital (Etzkowitz, 2008; Caragliu et al, 2009; Deakin, 2010). This model presupposes that the three helices operate in a complex urban environment, where market demand, governance, civic involvement and citizens' characteristics, along with cultural and social capital endowments shape the relationships between the traditional helices of university, industry and government.

The results of the above study has shown the analysis to baseline the development of smart cities in terms of their dual roles as generators of intellectual capital, creators of wealth and regulator of standards (University, Industry, Civil Society and Government), as well as supporting the social learning and knowledgetransfer abilities which are needed to meet the requirements of their regional innovation systems.

Although this analysis has been a useful start for understanding the main "governance" component of smart cities, it does not consider the other recognized aspects related to ecological sustainability. In addition, it does not recognize the number of relationships and feed backs between categories which are dependant upon the interconnected and systemic nature of the aspects involved.

The paper proposes a different model which involves the civil society as one of the main key actors, alongside the university, the industry and the government (Etzkowitz and Zhou,2006). This new framework has been used as a "control hierarcy" in a analytical network process (ANP) with the aim to identify and evaluate the performances of a smart city. The following section illustrates both the adopted model and the performance indicators used for this exercise.

\section{Modelling the Smartcity' performances}

Although there is no agreement on the exact definition of a smart city, a number of main dimensions of a smart city has been identified through a literature review exercise (Giffinger et al., 2007; Van Soom, 2009; Fusco Girard et al., 2009) and includes: smart economy; smart mobility; smart environment; smart people; smart living; and smart governance.

Based on the above components and on the triple helix approach (Etzkowitz and Zhou, 2006), a novel framework for classifying smart city performance indicators has been developed as shown in Table (1). As one can notice, both the main components/activities and the main actors/helices of a Smart city are represented. The identified clusters are: Smart Governance (related to participation); Smart Human Capital (related to people); Smart Environment (related to natural resources); Smart Living (related to the quality of life) and Smart Economy (related to competitiveness).

The source of data for this table are both literature review including EU projects' reports and Urban Audit dataset and indicators selected from statistics of European commission, European green city index, TISSUE, Trends and Indicators for Monitoring the EU Thematic Strategy on Sustainable Development of Urban Environment and smart cities ranking of European medium-sized cities. This includes more than 60 indicators classified in the five aforesaid clusters.

Furthermore, the authors of this study have identified the relations between the Smart Cities components by way of an Analytic Network Process (ANP). The ANP model consists of clusters (i.e. groups of homogeneous elements of a decision problem), elements (i.e. nodes of the network), interrelationship between clusters, and interrelationship between elements. It allows interactions and feedback within and between clusters and provides a process to derive ratio scales priorities from the elements (Saaty, 2005).

More specifically, a complex model was developed using the axes of the adopted Triple Helix, i.e. university, industry, government and civil society as a control hierarchy for structuring the sub-networks as shown in Figure 1. Each axe is organised by a sub-network consisting of:

- the five clusters representing the above mentioned smart cities component/activities including the relative selected indicators;

- a cluster of alternatives made by four policy visions (or prototypes) of smart cities as derived from the "Urban Europe" Joint Programme Initiatives (see report by: P. Nijkamp, K. Kourtik, 2011): Connected 
City (smart logistic \& sustainable mobility), Entrepreneurial City (economic vitality), Liveable City (ecological sustainability) and the Pioneer City (social participation \& social capital).

Table (1) Smart Cities components and indicators

\begin{tabular}{|c|c|c|c|c|c|}
\hline Revised & $\begin{array}{l}\text { SMART } \\
\text { Governence }\end{array}$ & $\begin{array}{l}\text { SMART } \\
\text { Economy }\end{array}$ & $\begin{array}{l}\text { SMART } \\
\text { Human }\end{array}$ & $\begin{array}{l}\text { SMART } \\
\text { Living }\end{array}$ & $\begin{array}{l}\text { SMART } \\
\text { Environment }\end{array}$ \\
\hline Triple Hel & \multicolumn{5}{|c|}{ INDICATORS } \\
\hline \multirow{3}{*}{ 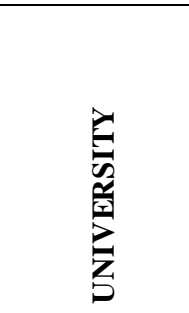 } & $\begin{array}{l}\text { No of universities } \\
\text { research centres in the } \\
\text { city }\end{array}$ & $\begin{array}{l}\text { Public expenditure on R\&D - \% of } \\
\text { GDP per head of city }\end{array}$ & 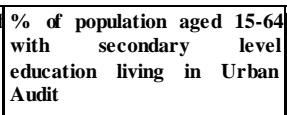 & 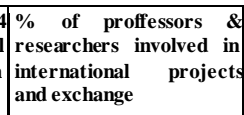 & $\begin{array}{l}\text { An assessment of the } \\
\text { ambitio usness of } \mathrm{CO} 2 \text { emissions } \\
\text { reduction strategy }\end{array}$ \\
\hline & \multirow[t]{2}{*}{$\begin{array}{l}\text { No. courses entirely } \\
\text { downloadable from the } \\
\text { internet / Total No. } \\
\text { Courses }\end{array}$} & $\begin{array}{l}\text { Public expenditure on education - \% } \\
\text { of GDP per head of city }\end{array}$ & $\begin{array}{l}\text { \% of population aged 15-64 } \\
\text { with high education living in } \\
\text { Urban Audit }\end{array}$ & \begin{tabular}{|l}
$4 \begin{array}{l}\text { Number of grants for } \\
\text { international } \\
\text { per year }\end{array}$ \\
mobility
\end{tabular} & \multirow[t]{2}{*}{$\begin{array}{l}\text { An assessment the extensiveness } \\
\text { of city energy efficiency } \\
\text { standards for buildings }\end{array}$} \\
\hline & & $\begin{array}{l}\text { Number of research grants funded } \\
\text { by international projects }\end{array}$ & $\begin{array}{l}\text { \% of inhabitants working in } \\
\text { education and in research \& } \\
\text { development sector }\end{array}$ & $\begin{array}{l}\text { \% of accescable courses } \\
\text { for PWD }\end{array}$ & \\
\hline \multirow{8}{*}{ 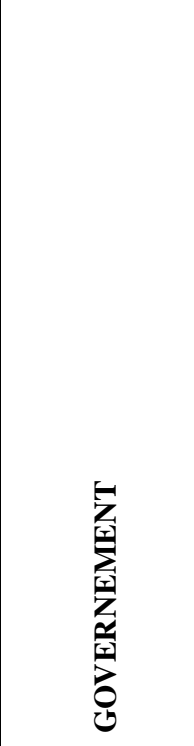 } & \multirow[t]{2}{*}{$\begin{array}{l}\text { E-government on-line } \\
\text { availability (\% of the } 20 \\
\text { basic services which are } \\
\text { fully available online) }\end{array}$} & $\begin{array}{l}\text { Gross Domestic Product per head of } \\
\text { city }\end{array}$ & $\begin{array}{l}\text { Voter turnout in national and } \\
\text { EU parliamentary elections }\end{array}$ & $\begin{array}{l}\text { Proportion of the area in } \\
\text { recreational sports and } \\
\text { leisure use }\end{array}$ & $\begin{array}{l}\text { Total annual energy } \\
\text { consumption, in gigajoules per } \\
\text { head }\end{array}$ \\
\hline & & \begin{tabular}{|l|l|} 
Debt of municipal authority per \\
resident
\end{tabular} & \begin{tabular}{|l|l|}
$\begin{array}{l}\text { Share of female city } \\
\text { representatives }\end{array}$ & \\
\end{tabular} & $\begin{array}{l}\text { Green space }(\mathrm{m} 2) \text { to } \\
\text { which the public has } \\
\text { access, per capita }\end{array}$ & $\begin{array}{l}\text { Efficient use of electricity (use } \\
\text { per GDP) }\end{array}$ \\
\hline & \multirow[t]{2}{*}{$\begin{array}{l}\text { Percentage of households } \\
\text { with computers }\end{array}$} & $\begin{array}{l}\text { Median or average disposable annual } \\
\text { household inco me }\end{array}$ & \multirow[t]{6}{*}{$\begin{array}{l}\text { City representatives per } \\
\text { resident }\end{array}$} & $\begin{array}{l}\text { Number of public } \\
\text { libraries }\end{array}$ & $\begin{array}{l}\text { Total annual rer water } \\
\text { consumption, in cubic metres } \\
\text { per head }\end{array}$ \\
\hline & & Unemploy ment rate & & $\begin{array}{l}\text { Number of theaters \& } \\
\text { cinemas }\end{array}$ & $\begin{array}{l}\text { Efficient use of water (use per } \\
\text { GDP) }\end{array}$ \\
\hline & \multirow{4}{*}{$\begin{array}{l}\text { Percentage of households } \\
\text { with Internet access at } \\
\text { home }\end{array}$} & \multirow{4}{*}{$\begin{array}{l}\text { Energy intensity of the economy } \\
\text { Gross inland consumption of energy } \\
\text { divided by GDP }\end{array}$} & & \multirow{2}{*}{$\begin{array}{l}\text { Health care expenditure } \\
-\% \text { of GDP per head of } \\
\text { city }\end{array}$} & Area in green space $(\mathrm{m} 2)$ \\
\hline & & & & & \begin{tabular}{|l}
$\begin{array}{l}\text { Geenhouse gas } \\
\text { intensity of energy consumptions }\end{array}$ \\
\end{tabular} \\
\hline & & & & \begin{tabular}{|l} 
Tourist overnight stays \\
in registered \\
accommodation in per \\
year per resident
\end{tabular} & $\begin{array}{l}\text { An assessment of the } \\
\text { comprehensiveness of policies to } \\
\text { contain the urban sprawl and to } \\
\text { improve and monitor } \\
\text { environmental performance }\end{array}$ \\
\hline & & & & & $\begin{array}{l}\text { Urban population exposure to } \\
\text { air pollution by particulate } \\
\text { matter - micrograms per cubic } \\
\text { metre }\end{array}$ \\
\hline \multirow{4}{*}{ 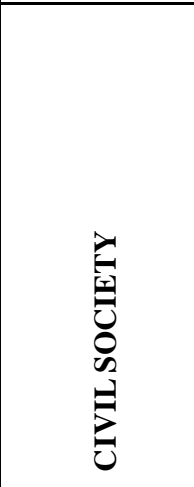 } & \multirow{4}{*}{ 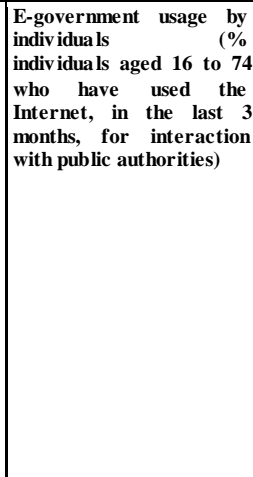 } & \multirow{4}{*}{ \% of projects funded by civil society } & For eign language $s$ kills & $\begin{array}{l}\text { Total book loans and } \\
\text { other media per resident }\end{array}$ & $\begin{array}{l}\text { The total percentage of the } \\
\text { working population travelling } \\
\text { to work on public transport, by }\end{array}$ \\
\hline & & & \begin{tabular}{|l|} 
Participation in Life-long \\
learning $(\%)$
\end{tabular} & $\begin{array}{l}\text { Museums visits per } \\
\text { inha bitant }\end{array}$ & $\begin{array}{l}\text { An assessment of the extent to } \\
\text { which citizens may } \\
\text { participate in environmental } \\
\text { decision-ma king }\end{array}$ \\
\hline & & & \begin{tabular}{|l|}
$\begin{array}{l}\text { Individua ls' level of computer } \\
\text { skills }\end{array}$ \\
\end{tabular} & \begin{tabular}{|lr}
$\begin{array}{l}\text { Theatre } \\
\text { attendance } \\
\text { inhabitant }\end{array}$ & cinema \\
& per \\
\end{tabular} & $\begin{array}{l}\text { An assessment of the } \\
\text { extensiveness of efforts to } \\
\text { increase } \\
\text { the use of cleaner transport }\end{array}$ \\
\hline & & & $\begin{array}{l}\text { Individua ls' level of internet } \\
\text { s kills }\end{array}$ & & $\begin{array}{l}\% \text { of citzens engaged in } \\
\text { environmental } \\
\text { sustainability oriented activity }\end{array}$ \\
\hline \multirow{4}{*}{ 药 } & \multirow[t]{4}{*}{$\begin{array}{l}\text { Number of research } \\
\text { grants funded by } \\
\text { companies, foundations, } \\
\text { institutes / No annual } \\
\text { scholarships }\end{array}$} & \multirow{2}{*}{$\begin{array}{l}\text { Employment rate in: } \\
- \text { High Tech \& creative industries } \\
- \text { Renewable energy \& energy } \\
\text { efficieny } \\
- \text { Financial intermediation and } \\
\text { business activities } \\
- \text { culture \& entertainment industry } \\
-\quad \text { commercial services } \\
- \text { transport and communication } \\
- \text { hotels and restaurants }\end{array}$} & \multirow{2}{*}{\begin{tabular}{|l} 
Patent applications per \\
inhabitant \\
s \\
d \\
s \\
n \\
\\
\end{tabular}} & \multirow[t]{2}{*}{$\begin{array}{l}\text { Number of enterprise } \\
\text { adopting } \text { ISO } 14000 \\
\text { standards }\end{array}$} & $\begin{array}{l}\text { The percentage of total energy } \\
\text { derived from renewable } \\
\text { sources, as a share of the city's } \\
\text { total energy consumption, } \\
\text { in terajoules }\end{array}$ \\
\hline & & & & & $\begin{array}{l}\text { Combined heat and power } \\
\text { generation }-\% \text { of gros } \\
\text { electricity generation }\end{array}$ \\
\hline & & All companies (total number) & \multirow{2}{*}{$\begin{array}{l}\text { Employment rate in } \\
\text { knowledge-intensive sectors }\end{array}$} & \multirow{2}{*}{$\begin{array}{l}\text { Rate of } \\
\text { underta keople } \\
\text { based training }\end{array}$} & \multirow[t]{2}{*}{$\begin{array}{l}\text { Rate of rycycled waste per tota } \\
\text { lg of waste produced }\end{array}$} \\
\hline & & $\begin{array}{l}\text { Number of local units ma nufacturing } \\
\text { High Tech \& ICT products }\end{array}$ & & & \\
\hline
\end{tabular}




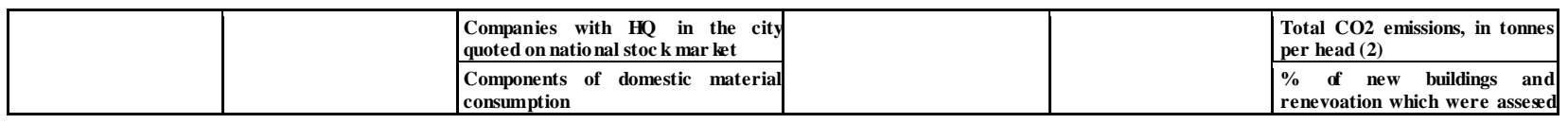

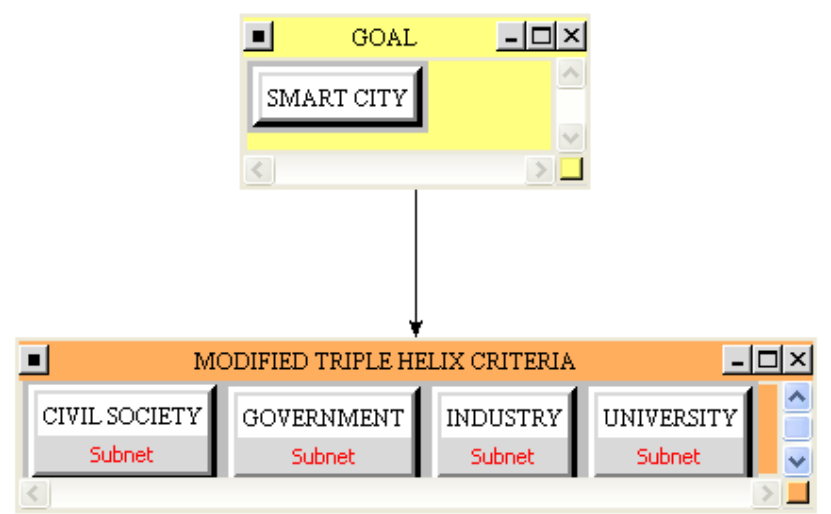

Figure (1) The main network

As an example, Figure 2 shows the Civil Society sub-network where both Smart Governance and the Smart Economy clusters include only one element, respectively: "E-gov usage by individuals" and "Percentage of projects funded by civil society". This nodes' organisation allows inner connections in the other clusters as in the Smart Human Capital, where the "Foreign language skills" influence other nodes, such as "Individuals level of computer skills" and "Individuals level of internet skills".

Bidirectional relationships are identified as follows:

- Smart Economy and Smart Environment, where the "Percentage of projects funded by civil society" is the direct cause of the "Relationship to percentage of citizens engaged in environmental and sustainability oriented activities";

- Smart Human Capital and Smart Living, where the "Participation in life-long learning" is connected by all smart living nodes ("Museums visit per inhabitant", "Theatre \& cinema attendance per inhabitant" and "Total book loans and other media per resident").

Additional mono-directional connections can be identified between the other clusters.

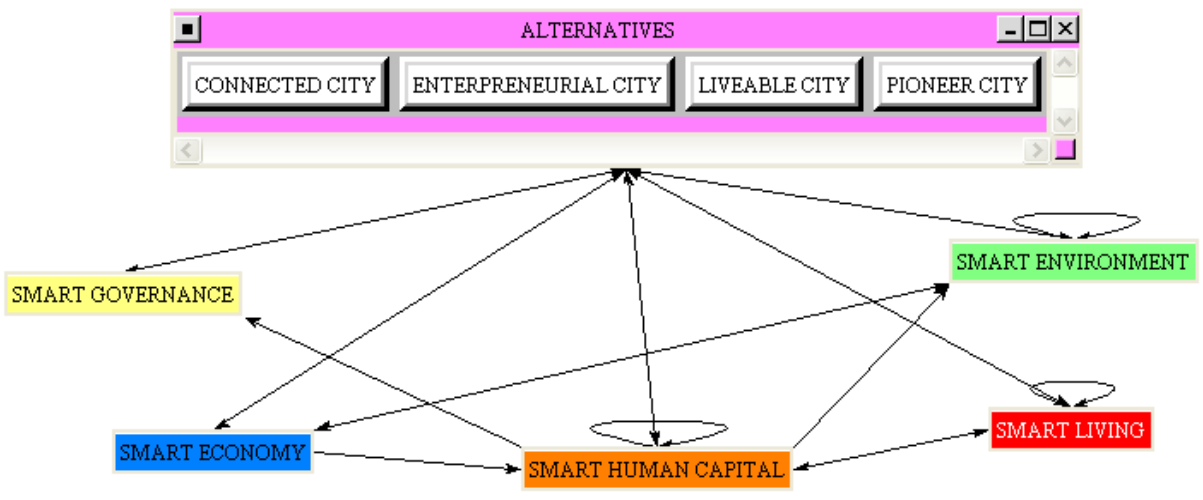

Figure (2) The Civil Society sub-network

This model will be used for investigating the interrelations between smart cities components and actors and finally for verifying whether: the cities are "smart"; if not, whether they are moving in the right direction.

\section{Conclusions and further steps}


This paper has illustrated an on-going study in the field of Smart cities' evaluation. The analys is has started from a revised notion of triple helix considering that civil society usually plays a prominent role toward the realization of sustainable development in cities (Etzkowitz and Zhou, 2006).

In order to assess the connections between Smart city development and this institutionalization of the Triple Helix, a ANP model has been developed. This allows the capture both the triple helix components of a smart urban development and the recognized components of a smart city.

The assessment exercise still requires all the following steps: a) Developing pairw ise comparison of both elements and clusters to establish relations within the structure; b) Achievement of the final priorities. The development of the above methodological steps entails the participation of main city stakeholders, offering a reflexive learning opportunity for the cities to measure what options exist to improve their performances. It will be the tasks of authors' future activities.

\section{REFERENCES}

Caragliu, A., Del Bo, C. and Nijkamp. P. (2009). Smart Cities in Europe, paper presented to the Creating Smarter Cities Conference, Edinburgh Napier University, March 2009.

Deakin, M. (2010) SCRAN: the Smart Cities (inter) Regional Academic Network Supporting the Development of a Trans-National Comparator for the Standardisation of eGovernment Services, in Reddick, C. ed. Comparative E-government: An Examination of E-Government Across Countries, Springer Press, Berlin.

Etzkow itz H. and Zhou C. (2006). Triple Helix twins: innovation and sustainability, Science and Public Policy, vol. $33, \mathrm{n}^{\circ} .1$, pp. $77-83$

Ezkowitz, H. (2008). The Triple Helix: Universtiy, industry and Government, Routledge, London.

Fusco Girad, L., Lombardi, P., Nijkamp, P. (2009). Creative Urban Design and Development (special issue), International Journal of Services Technology and Management: Vol. 13, No. 2/3/3, pp.111-115

Gabe, T.M. (2006). Growth of Creative Occupations in U.S. Metropolitan Areas, Growth and Change, vol. 37, no. 3, pp. 396-415

Giffinger, R., Fertner, C., Kramar, H., Kalasek, R., Pichler-Milanovic, N., Meijers, E. (2007). Smart cities Ranking of European medium-sized cities, Centre of Regional Science, Vienna UT, October 2007. Retrieved November 25, 2010, from http://www.smart-cities.eu

Hollands, R. (2008). “Will the real smart city please stand up?”, City, 12 (3), 303-320.

Nijkamp, P, Kourtik, K. (2011). Joint Programming Initiative (JPI) on Urban Europe. Global challenges and local responses in the urban century, a scoping document, 27, VU University Amsterdam, 2011.

Lombardi P., Giordano S., Caragliu A., Del Bo C., Deakin M., Nijkamp P., Kourtit K. and Farouh H. (2011). An Advanced Triple-Helix Network Model for Smart Cities Performance, In Y. Ozge (Ed.), Green and Ecological Technologies for Urban Planning: Creating Smart Cities, IGI Global (in press).

Lombardi P., Cooper I, Paskaleva K \& Deakin M. (2009). The Challenge of Designing User-Centric eServices: European Dimensions. In C.Reddick (Ed), Strategies for Local E-Government Adoption and Implementation: Comparative Studies. Idea Group Publishing, Hershey.

Nijkamp, P. and Kourtik, K. (2011). Joint Programming Initiative (JPI) on Urban Europe. Global challenges and local responses in the urban century. A scoping document, 27, VU University Amsterdam, 2011.

Quality of Life in Twelve of New Zealand's Cities, Report 2007. Retrieved November 25, 2010, from http://www.qualityofl ifeproject.govt.nz

Saaty, T.L. (2005). Theory and Applications of the Analytic Network Process, RWS Publications, Pittsburgh. 
Van Soom, E. (2009). Measuring levels of supply and demand for e-services and e-government: a toolkit for cities. Smart Cities Research Brief, N. 3, Retrieved February 25, 2009, from

http://www.smartcities.info/research-briefs.

Smart Cities North Sea Intereg 4B project (2007-2013)

http://www.northsearegion.eu/ivb/projects/details/\&tid=84 